\title{
The Study on the Elevation Design of Apartments Incorporating Daylight Performance
}

\author{
Ji-Eun Lee and Kang Up Lee
}

\begin{abstract}
Understanding the distribution of daylight in a room is essential for predicting the visible comfort and energy saving of each unit. The factors of the elevation design actually decide the building performance because the sun has the fixed pattern. In addition, the indoor environmental conditions are varied according to the location and story of each dwelling even though having the same shape and orientation. For this research, the different types of daylight performance metrics were simulated with Ecotect. According to the simulation of Ecotect, the positional characteristics were shown by the daylight distribution and energy consumption. This paper presents an overview of the apartment facade design by applying four type models with varied WWR. The main results focused on finding the better WWR, and deducing the design to overcome the performance gap.
\end{abstract}

Index Terms - Daylight performance, daylight distribution, energy saving, elevation design for passive housing.

\section{INTRODUCTION}

Evaluated by just one criteria of good daylight environment is difficult; however, maintaining a pleasant illumination with the natural light without artificial light has the best performance in terms of lighting, heating and cooling. Namely, it plays a crucial role in energy conservation. However, the condition of the appropriate illumination does not match the criteria to make the proper thermal environment For example, if the wall area was more than $30 \%$, the energy consumption associated with heating and cooling would increase rapidly. Thus not more than 30 percent is better for the energy efficiency, but in all cases, the appropriate illumination cannot be ensured [1].

Window-to-wall ratio (WWR) to control amount of solar radiation is an important evaluation index related to the building's energy performance in the domestic and overseas. However, the apartment elevation has the uniform and repetitive pattern regardless of the location of each dwelling. The most efficient strategy based on environmental performance is optimized the conditions of sunlight by the orientation of each unit and the building shape. Moreover, in the course of these plans, the influx of sunshine should be investigated how to affect the indoor environment and people's visible comfort. The daylight distribution and energy load of each dwelling was analyzed using ECOTECT2010. WWR decides the window size, and measures of daylight performance such as DF and DA explain the daylight

Manuscript received March 15, 2013; revised July 5, 2013.

The authors are with the Department of Architectural Design, Han-Yang University (e-mail: archijieun@gmail.com, jeanie@Hanyang.ac,kr). distribution. In addition, the thermal performance gap between dwellings was checked by heating and cooling load. Therefore, this study analyzed the difference between the energy load and light environment depending on the location of each dwelling and set WWR to have the best performance in flat type apartments. In addition, it proposed the method how to design the apartment elevation.

\section{FRAMEWORK OF DAYLIGHT PERFORMANCE}

\section{A. Evaluation of the Natural Light and Energy Consumption}

Measures for evaluating the natural light environment have periodically changed. First, it was evaluated with both Daylight Factor (DF) whether to exceed the daylight factor of $2 \%$ in $75 \%$ of the work plane area in Green building rating system version 2 of 2005 and to achieve a minimum illumination level of $25 \mathrm{fc}$ on a clear equinox day at noon in LEED EQ 8.1 rev2 of 2009 [2]. A building was whether satisfied or not were different depending on the applied standards in LEED, and LEED2.1 is relatively more difficult [3]. Second, DA (daylight autonomy) taken from LEED v4 considers the occupying hours and the amount of usage the artificial lighting. More than 500 lux is usually needed, and the occupying hours from $7 \mathrm{am}$ to $5 \mathrm{pm}$ is set for the calculation of time percentages in one year. However, it has a limit to describe the daylight distribution. DA is divided into each section depending on illumination levels in order to show its distribution and applied it to the school as a model [4]. DAmax which defined as the range of over-illumination measures the ratio of exceed 10 times more than the standard. This can explain how often and where to induce a feeling of discomfort due to direct solar radiation.

Third, UDI (Useful Daylight Illumination) evaluates for the quantity and quality of natural light in working hours with the wide range of the useful interior lighting (100-2,000 lux) Finally, the certain continuous sunshine hours which are based on the winter solstice (December 21) should be ensured in the domestic building standards. All buildings regardless of function of the building should be provided more than two sunshine hours during the six hours from 9:00am to 3:00pm or four sunshine hours during the eight hours from 8:00am to $16: 00 \mathrm{pm}$. In addition, the standard of housing performance indication system chooses the natural lighting ratio. This research will explain the distribution of the indoor illumination of each dwelling with these four measurements: DF representing the average illumination, DA evaluating the time provided enough daylight, $\mathrm{DA}_{\mathrm{con}}$ (DA continuous) 
describing daylight distribution, $\mathrm{DA}_{\max }$ giving the discomfort.

Next, in energy consumption, despite Energyplus makes possible to drive the more realistic results, Autodesk's ECOTECT 2011 was used to evaluate the energy consumption [5]. It fits the purpose of this paper to follow a relatively simple process for reviewing the building forms at the schematic or design development stage. In addition, finding the optimal design is aimed at relative comparisons rather than absolute ones. However, the measurement result of the energy efficiency by the simulation creates a big difference depending on cladding materials and the thermal bridging with the adjacent particles.

\section{B. National Window Design Guideline for Energy Saving}

The excellence design evaluation has been judged objectively with the certified system such as energy-saving performance or green building certification. First, Green building certification in Korea or guidelines for it has scored the individual critetia using EPI (Energy Performance Index) from 2002. However, the system 'total energy consumption' in Seoul utilizes the BESS (Building Energy Simulation for Seoul Ver. 4.0) software for calculation. LEED recommends the calculation by a computer simulation. In BREEAM-CSH (Codes for Sustainable Home) in the UK, SAP 2009 has been used as a tool to recommend the calculating method by computers [6].

Design guidelines for domestic energy savings are presented as different criteria by region (see Table I ). The Energy performance certification and Suncheon guidelines recommend minimizing the area of the northern window; however, 'windows design guidelines for energy saving' recommend to minimize the area of the east-west window. The flat-type apartment as the model of this research takes advantage in these aspects, because facing on the south, the east and west facing window in normal could not be installed.

TABLE I: WINDOWS DESIGN GUIDELINES FOR ENERGY SAVING IN KOREA

\begin{tabular}{|c|c|c|c|c|c|c|}
\hline & & $\begin{array}{l}\text { 1.Energy } \\
\text { Perfommance } \\
\text { Index(EPI) }\end{array}$ & $\begin{array}{c}\text { 2.Green } \\
\text { B/D Design } \\
\text { in Seoul }\end{array}$ & $\begin{array}{l}\text { 3. Green B/D } \\
\text { Guideline in } \\
\text { Incheon }\end{array}$ & $\begin{array}{l}\text { 4. Suncheon } \\
\text { guideline }\end{array}$ & $\begin{array}{l}\text { 5. Windows } \\
\text { design } \\
\text { guidelines for } \\
\text { energy saving }\end{array}$ \\
\hline \multicolumn{2}{|c|}{ Target area } & $\begin{array}{l}\text { All in } \\
\text { Korea }\end{array}$ & Seoul & Incheon & Suncheon & $\begin{array}{c}\text { Southern and } \\
\text { central area }\end{array}$ \\
\hline \multicolumn{2}{|c|}{$\begin{array}{c}\text { Applicable } \\
\text { B/D }\end{array}$} & $\begin{array}{c}\text { Certified } \\
\text { green } \mathrm{B} / \mathrm{D}\end{array}$ & $\begin{array}{c}\text { APT \& } \\
\text { Townhouse }\end{array}$ & $\begin{array}{c}\text { 50units } \\
\text { Housing }\end{array}$ & Apartment & All B/D \\
\hline \multirow{2}{*}{$\begin{array}{l}\text { Light } \\
\text { criteria }\end{array}$} & unit & $\begin{array}{c}\text { Win./Fl. } \\
\text { area }\end{array}$ & $\begin{array}{c}\text { Wall-win./ } \\
\text { wall }^{1}\end{array}$ & Win./Fl. area & $\begin{array}{c}\text { Wall-win./ } \\
\text { wall }^{1}\end{array}$ & $\begin{array}{l}\text { Win.-to-wall } \\
\text { ratio }^{2}\end{array}$ \\
\hline & content & $10 \% \uparrow$ & $25 \% \uparrow$ & $1 / 7 \uparrow$ & $50 \% \uparrow$ & $40 \% \uparrow$ \\
\hline
\end{tabular}

[Note] 1) wall-window area / wall area: the ratio of the surface area except window area to the total surface area of the exterior wall. 2) Window-to-wall ratio: the ratio of window area to the exterior wall area: the zone from floor to ceiling.

\section{Application of Design Standards}

The previous criteria are meaningful to set the standard to measure the illumination and energy performance of the designed façade. These measurement standards are different and somewhat subjective to define standards for comfort. Thus, they cannot unify into one criterion. However, there were common considerations for determining the window design standard, as follows: First, all the criteria assume the energy-saving performance. In addition, the design to have the lowest energy consumption with the same window area is recommended. However, the method is divided into two ways. One is to provide the guideline and follow them; another is to simulate the building performance and verify that it is enough. The latter method is effective to reduce the gap between the planning and actual environment. Second, it evaluates the performance of the whole building. Units in apartments have the different condition depending on the location; however, the total amount of the performance has been used for verifying green building. Therefore, this research set the model with reference to the design criteria and feedback on the results. In addition, it analyzed the characteristic related to the daylight environment of each unit and proposed how to optimize the design.

\section{EVAluATION OF DAYLIGHT PERFORMANCE}

The flat apartment is the representative shape of apartment buildings in South Korea. They formed 56\% in 919 buildings of 74 complexes designed after 2007 [7]. In addition, '- 'shape building took $68 \%$ in these flat apartments. The scope of this study is to provide the difference of environmental performance depending on the location of each unit. Comparison factors are horizontal positioning of each unit, the floor level, the window-to-wall ratio (WWR), pitch of building. Thus, four façade types were relatively compared to each other, which were fixed reference to the previous design guideline and many cases.

\section{A. Modeling Overview}

The model was created in the ECOTECT2011. Each measuring point is $70 \mathrm{~cm}$ from the floor, the indoor surface floor has $60 \mathrm{~cm}$ module size grid. That consists of 362 points considering the reflection from the wall. It is common that flat type apartments have windows opening in north and south sides (see Table II ). The master plan is common to face to parallel to the South buildings. Therefore, the daylight environments of middle and east side units as representative locations were measured because east and west units have the symmetrical conditions. .

TABLE II: MODELING OVERVIEW FOR MEASUREMENT

\begin{tabular}{l|l}
\hline \hline Location/Azimuth orientation & Incheon City / True south \\
\hline Floor area per dwelling(Stories) & $129.3 \mathrm{~m}^{2}(20$ stories $)$ \\
\hline FL.-to-FL. height & $2.8 \mathrm{~m}($ Ceiling height:2.3m)/ \\
\hline
\end{tabular}

B. Setting the Measurement Condition

The depth of a building was decided in accordance with the 
result of this formula and it was similar to many cases [8]. Limiting depth was $7.76 \mathrm{~m}$

Limiting depth $=\left\{2 /\left(1-R_{\text {mean }}\right)\right\} /\left(1 / w+1 / h_{\text {window-head height }}\right)(1)$

$R_{\text {mean }}$ : mean surface reflectance/ $w$ : room width in meters

The result to analyze cases of the Montreal presented three conclusions in terms of WWR and the orientation [1]: 1) Facing the south, the DA and energy savings range up to, 2) The south-facing window area ratio increased by more than $30 \%$, DA decreased to less than $76 \%$, 3) $20 \%$ of WWR is difficult to satisfy the stable DA $(50 \%)$ based on the standard of 500lux. A1 type was the typical one. A1 type had $31 \%$ WWR and $20 \%$ window-to-floor area ratio, and the south to north side window area ratio 1.8:1 (see Table III). A2 with the same window size as A1 had the different window shape. In addition, the DF calculated by this formula considering the impact of other building's shadow compared to them by ecotect simulation.

TABLE III: CHARACTERISTICS OF WALL OPENINGS TYPE

\begin{tabular}{|c|c|c|c|c|c|c|c|c|c|c|c|}
\hline & \multicolumn{3}{|c|}{ WWR(\%) } & \multirow{2}{*}{$\begin{array}{l}\text { Win.-t } \\
\text { o-FL. } \\
\text { Area }\end{array}$} & \multicolumn{4}{|c|}{ Window Area $\left(m^{2}\right)$} & \multicolumn{3}{|c|}{ DF by (1) } \\
\hline & Total & $\begin{array}{r}\text { South } \\
\text { facade }\end{array}$ & \begin{tabular}{|l|} 
North \\
facade
\end{tabular} & & Total & \begin{tabular}{|l|} 
Right \\
South
\end{tabular} & $\begin{array}{c}\text { Left } \\
\text { South }\end{array}$ & North & $1^{\text {st }} \mathrm{FL}$. & \begin{tabular}{c|c}
$9^{\text {th }}$ \\
FL.
\end{tabular} & $\begin{array}{l}20^{\text {th }} \\
\text { FL. }\end{array}$ \\
\hline A1 & 0.31 & 0.2 & 0.11 & 0.2 & 26.3 & 14.8 & 2.2 & 9.3 & 2.06 & 2.69 & 3.94 \\
\hline A2 & 0.31 & 0.2 & 0.11 & 0.2 & 26.3 & 12.6 & 4.4 & 9.3 & 2.06 & 2.69 & 3.94 \\
\hline $\mathrm{B}$ & 0.33 & 0.22 & 0.11 & 0.22 & 28 & 14.8 & 3.9 & 9.3 & 2.19 & 2.86 & 4.19 \\
\hline $\mathrm{C}$ & 0.35 & 0.24 & 0.11 & 0.23 & 29.8 & 14.8 & 5.7 & 9.3 & 2.33 & 3.05 & 4.46 \\
\hline \multicolumn{6}{|c|}{ A1 type } & \multicolumn{6}{|c|}{ A2 type } \\
\hline \multicolumn{6}{|c|}{ 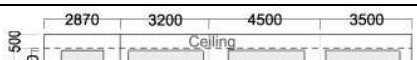 } & \multirow[b]{2}{*}{$\frac{8}{4}$} & & & & & \\
\hline 总点 & & & & & & & & & & & \\
\hline
\end{tabular}

\section{Analysis of the Lighting Performance}

First, checking whether DF is over 1.5 by the British BREEAM standards, all measuring points are more than $1.5 \% \mathrm{DF}$ in the case of no shadow effect; however, if there were the shadow of other buildings, those in $4 \sim 5.8 \mathrm{~m}$ from the south window is lower than $1.5 \% \mathrm{DF}$ in $1^{\text {st }}$ floor of the middle unit (see Table IV ). However, this range is normally the secondary zone such as the corridor (see Fig. 1). The types to make up for these weak points should have more window areas in middle units of $1^{\text {st }}$ and $10^{\text {th }}$ floor.

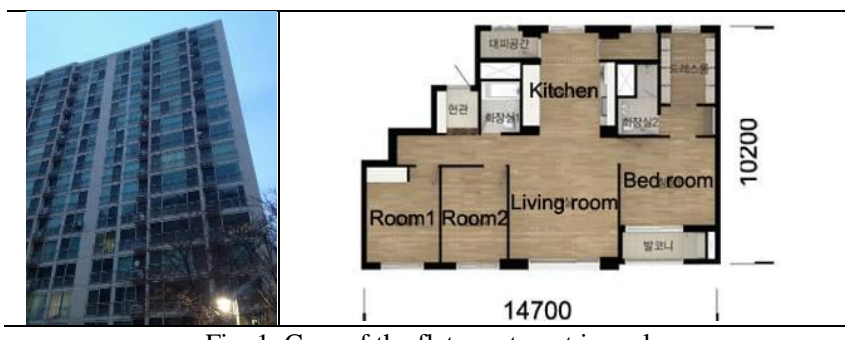

Fig. 1. Case of the flat apartment in real.

Moreover, east dwellings have bigger gaps than middle ones which had 0.5 0.8 percent lower DF overall depending on the floor height. The differences between light environments in all units could be reduced through applying the different size of windows. However, having the same average illumination in all units is unnecessary. The reason is that the energy consumption or the floor area having the uncomfortable illumination would be different. Thus, meeting the recommended level of illumination should be firstly considered, and other criteria should be solved in consecutive order.

TABLE IV: DAYLIGHT FACTOR DEPENDING ON THE LOCATION AND OPENING TYPE

\begin{tabular}{|c|c|c|c|c|c|c|c|}
\hline \multirow{2}{*}{\multicolumn{2}{|c|}{$\begin{array}{c}\begin{array}{c}\text { Story and } \\
\text { shadow range }\end{array} \\
\text { Shadow effect }\end{array}$}} & \multicolumn{2}{|c|}{$\begin{array}{l}1^{\text {st }} \text { floor } \\
(100 \% \text { shading) }\end{array}$} & \multicolumn{2}{|c|}{$\begin{array}{l}9^{\text {th }} \text { floor } \\
\text { (partial shading) }\end{array}$} & \multicolumn{2}{|c|}{$\begin{array}{l}20^{\text {th }} \text { floor } \\
\text { (no shading) }\end{array}$} \\
\hline & & No & Yes & No & Yes & No & Yes \\
\hline \multirow{3}{*}{$\begin{array}{l}\text { Midd } \\
\text { le } \\
\text { unit }\end{array}$} & A1 & 3.63 & 3.12 & 3.84 & 3.49 & 3.87 & 3.87 \\
\hline & \multirow{2}{*}{$\begin{array}{l}\text { Opti } \\
\text { mal }\end{array}$} & 3.95 & 3.36 & 3.91 & 3.63 & 3.94 & 3.93 \\
\hline & & (C) & (C) & (B) & (B) & (A2) & (A2) \\
\hline \multirow{3}{*}{$\begin{array}{l}\text { East } \\
\text { unit }\end{array}$} & A1 & 4.02 & 3.7 & 4.53 & 4.22 & 4.58 & 4.58 \\
\hline & \multirow{2}{*}{$\begin{array}{c}\text { Opti } \\
\text { mal }\end{array}$} & 4.27 & 3.82 & 4.58 & 4.27 & 4.58 & 4.58 \\
\hline & & (B) & (B) & (A2) & (A2) & (A1) & (A1) \\
\hline
\end{tabular}

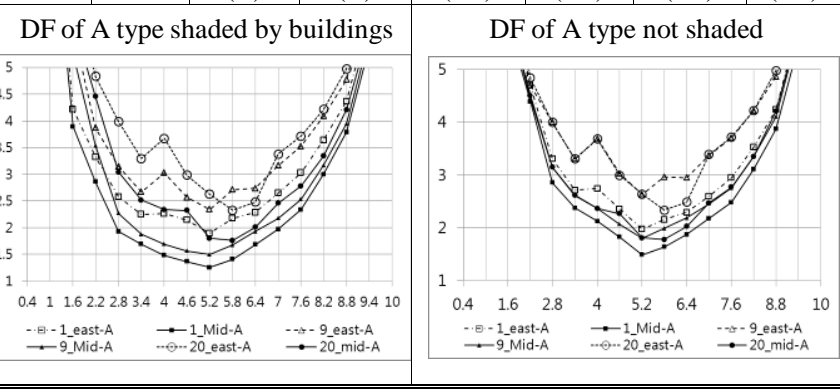

TABLE V: AVERAGE DAYLIGHT AUTONOMY IN EACH DWELLING(UNIT : \%)

\begin{tabular}{c|c|c|c|c|c|c|c}
\hline \hline \multicolumn{2}{c|}{ Window type } & \multicolumn{2}{c|}{$1^{\text {st }}$ floor } & \multicolumn{2}{c|}{$9^{\text {th }}$ floor } & \multicolumn{2}{c}{$20^{\text {th }}$ floor } \\
\hline \multirow{2}{*}{$\begin{array}{c}\text { Midd } \\
\text { le } \\
\text { unit }\end{array}$} & A1 & 61.73 & 52.28 & 67.35 & 59.6 & 67.52 & 67.63 \\
\cline { 2 - 8 } & Optim & 65.73 & 56.6 & 67.79 & 61.32 & 67.95 & 67.9 \\
\cline { 2 - 8 } East & A1 & 71.25 & 68.9 & 79.02 & 75.9 & 79.29 & 79.3 \\
\cline { 2 - 8 } unit & $\begin{array}{c}\text { Optim } \\
\text { al }\end{array}$ & 74.87 & 70.6 & 79.10 & 75.9 & 79.29 & 79.3 \\
\cline { 2 - 8 } & (B) & $(\mathrm{B})$ & $(\mathrm{A} 2)$ & $(\mathrm{A} 2)$ & $(\mathrm{A} 1)$ & $(\mathrm{A} 1)$
\end{tabular}

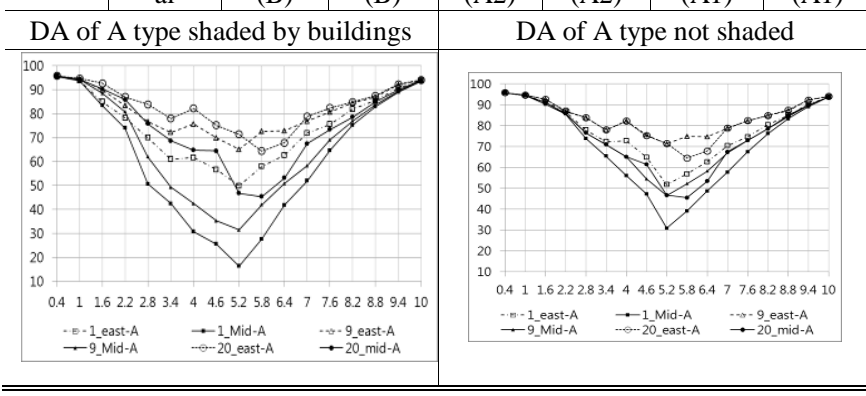

Second, DA present the similar changing pattern according to the story, and under the condition shaded by buildings the aspect came into clear. The types could be classified by 3 groups by the distribution of the illumination: 1) lack of daylight: middle units in $1^{\text {st }}$ and $9^{\text {th }}$ floor, 2) a bit short: the middle unit in $20^{\text {th }}$ floor, the east unit in $1^{\text {st }}$ floor, 3 ) enough : east units in $10^{\text {th }}$ and $20^{\text {th }}$ floors. Also, according to the location, results applied to the same A2 had big differences between middle $20^{\text {th }}$ and east $10^{\text {th }}$ floor (see Table V). Namely, though middle $20^{\text {th }}$ one locates no-shaded zone, the mean DA was $8 \%$ lower than it of $9^{\text {th }}$ east one. Thus, DA in the east side was more uniformly distributed and higher than it of middle unit in total. Moreover, east units were less affected by shadow of other ones. However, these results showed the ratio to cover all ranges that exceeded the standard illumination(500lux). Thus, there were certain limitations to predict additional problems to increase the heat from the sun 
in summer and visual discomfort of occupants.

Third, $\mathrm{DA}_{\text {con }}$ and $\mathrm{DA}_{\max }$ present the illuminance distribution as the area ratio. The condition that the area with proper illumination exceeded $60 \%$ of total floor area can be regarded as the good daylight environment [4]. In middle, first floor, despite applying $\mathrm{C}$ with the widest window area without shades, the area (55.2\%) with more than 300lux was less than $60 \%$ in total, and the area with $\mathrm{DA}_{\max }(5.25 \%)$ was more than $5 \%$. This imbalance of the illuminance was improved due to impact of shade. However, the whole illumination was lower. On the other hand, in the east units, though the window area of A1 was the same as it of A2, A2 of the $10^{\text {th }}$ and $\mathrm{A} 1$ of $20^{\text {th }}$ floor had the better lighting distribution. In addition, considering the range of the uncomfortable illumination in the same group drawn by the graph of DA and DF, A2 could provide the better condition than $\mathrm{B}$ to the middle $20^{\text {th }}$ floor. Like this, B was better than A2 for the east $1^{\text {st }}$ floor. Thus, the window models were regrouped (see Table VI).

TABLE VI: ILLUMINATION UNIFORMITY AND DISTRIBUTION(UNIT : \%)

\begin{tabular}{|c|c|c|c|c|c|c|}
\hline & \multicolumn{2}{|c|}{$1^{\text {st }}$ floor } & \multicolumn{2}{|c|}{$10^{\text {th }}$ floor } & \multicolumn{2}{|c|}{$20^{\text {th }}$ floor } \\
\hline $\begin{array}{l}\text { Middle unit } \\
\text { (shaded) }\end{array}$ & A1 & $C^{*}$ & A1 & B* & A1 & $\mathbf{A} 2 *$ \\
\hline $\mathrm{DA}_{\text {con }}>40 \%$ & 62.7 & 69.3 & 76.8 & 80.7 & $\begin{array}{r}91 . \\
2\end{array}$ & 93.4 \\
\hline $\mathrm{DA}_{\mathrm{con}}>60 \%$ & 39.2 & 42.5 & 46.7 & 48.3 & $\begin{array}{r}62 . \\
4\end{array}$ & 63.5 \\
\hline $\mathrm{DA}_{\text {con }}>80 \%$ & 25.7 & 28.4 & 30.4 & 32.0 & $\begin{array}{r}33 . \\
1 \\
\end{array}$ & 35.1 \\
\hline $\mathrm{DA}_{\max }>5 \%$ & 3.3 & 4.4 & 3.9 & 4.7 & 4.1 & 4.4 \\
\hline East unit (shaded) & A1 & B* & A1 & $\mathbf{A} 2 *$ & $\underset{*}{\mathbf{A 1}}$ & $\mathrm{A} 2$ \\
\hline $\mathrm{DA}_{\mathrm{con}}>40 \%$ & 96.7 & 97.8 & 99.4 & 99.4 & $\begin{array}{r}99 . \\
2\end{array}$ & 99.2 \\
\hline $\mathrm{DA}_{\mathrm{con}}>60 \%$ & 66.3 & 72.4 & 89.5 & 90.3 & $\begin{array}{r}94 . \\
8 \\
\end{array}$ & 94.5 \\
\hline $\mathrm{DA}_{\mathrm{con}}>80 \%$ & 30.1 & 31.2 & 38.7 & 39.5 & $\begin{array}{r}42 . \\
8\end{array}$ & 45.9 \\
\hline $\mathrm{DA}_{\max }>5 \%$ & 3.6 & 4.1 & 3.9 & 5.0 & 5.0 & 5.3 \\
\hline \multicolumn{7}{|c|}{ [Note] $*$ : better alternative } \\
\hline \multicolumn{3}{|c|}{ Distribution of A1 type } & \multicolumn{4}{|c|}{ Distribution applied better types } \\
\hline
\end{tabular}

\section{Evaluation of the Energy Performance}

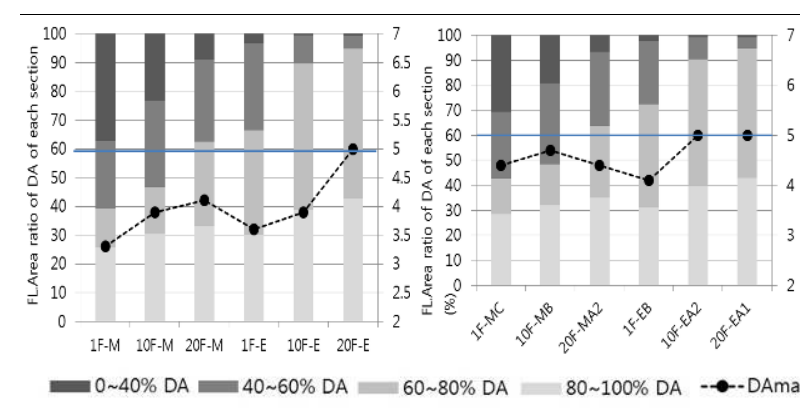

Fig. 2. Graph of daylight distribution

In the middle units, the heat energy becomes the equilibrium state by heat exchanger to the neighbor ones, whereas side ones lose so much heat energy to the outside air. Ecotect simulation has disadvantages that these results by thermal bridging are not calculated, and just considered about the location. The energy loads of the middle stories are relatively low (see Table VII). These results made the same changes as the ratio of direct solar, because the more direct solar was provided, the higher indoor temperatures in winter would be. In addition, the higher heat and cooling index was, the higher energy efficiency would be as the passive housing. However, the result in this research was not matched due to more heat loads. It can be improved by the roof material with lower thermal transmittance. Thus, the energy load became different depending on the location of windows with the same size, though the energy load was lower in the situation that the dwelling is not faced on the outside air and have smaller window area.

TABLE VII: ENERGY CONSUMPTION DEPENDING ON THE LOCATION UNDER SHADED

\begin{tabular}{|c|c|c|c|c|c|c|c|c|}
\hline \multirow{2}{*}{ Location } & \multirow{2}{*}{ storey } & \multicolumn{5}{|c|}{ Energy loads $\left(\mathrm{KWh} / \mathrm{m}^{2}, \%\right)$} & \multirow{2}{*}{\begin{tabular}{|c|} 
Direct \\
Sol. \\
$(\%)$
\end{tabular}} & \multirow{2}{*}{$\begin{array}{l}\text { H\&C } \\
\text { index }\end{array}$} \\
\hline & & \multicolumn{2}{|c|}{ Heat load } & \multicolumn{2}{|c|}{ Cooling load } & \multirow{2}{*}{$\begin{array}{l}\text { Total } \\
63859 \\
\end{array}$} & & \\
\hline A1 & $1 \mathrm{f}$ & 61140 & 95.7 & 2720 & 4.3 & & 12.3 & 1.05 \\
\hline Mid & 9f & 58654 & 95.1 & 3040 & 4.9 & 61694 & 12.3 & 1.08 \\
\hline unit & $20 \mathrm{f}$ & 62351 & 95.3 & 3064 & 4.7 & 65415 & 12.1 & 1.12 \\
\hline \multirow{3}{*}{$\begin{array}{c}\text { A1 } \\
\text { East } \\
\text { unit }\end{array}$} & 1f & 60537 & 95.6 & 2798 & 4.4 & 63335 & 17.1 & 1.05 \\
\hline & 9f & 58163 & 94.9 & 3125 & 5.1 & 61288 & 17.2 & 1.08 \\
\hline & $20 \mathrm{f}$ & 62055 & 95.2 & 3155 & 4.8 & 65210 & 17.1 & 1.13 \\
\hline \multirow{3}{*}{$\begin{array}{l}\text { Alt. } \\
\text { Mid }\end{array}$} & $1 \mathrm{f}(\mathrm{C})$ & 63987 & 95.9 & 2715 & 4.1 & 66710 & 12.8 & 1.08 \\
\hline & $9 \mathrm{f}(\mathrm{B})$ & 60049 & 95.2 & 3042 & 4.8 & 63090 & 12.5 & 1.07 \\
\hline & $20 f(A 2)$ & 62542 & 95.3 & 3056 & 4.7 & 65598 & 12.1 & 1.13 \\
\hline \multirow{3}{*}{$\begin{array}{l}\text { Alt. } \\
\text { East }\end{array}$} & $1 \mathrm{f}(\mathrm{B})$ & 61654 & 95.6 & 2817 & 4.4 & 64471 & 18.6 & 1.07 \\
\hline & $9 f(A 2)$ & 58154 & 94.9 & 3126 & 5.1 & 61280 & 17.3 & 1.08 \\
\hline & $20 f(A 2)$ & 62286 & 95.2 & 3152 & 4.8 & 65438 & 17.1 & 1.13 \\
\hline
\end{tabular}

In the light environment, east dwellings on higher floor are relatively better. In the energy consumption, the middle-position dwellings in the intermediate layer are relatively advantageous. From among these, the intermediate layer of about 9 floors has reliably the superior performance to the uppermost and lowermost layer.

\section{The Window Design BASED ON THE PERFormance}

\section{A. Performance Depending on the Window Area}

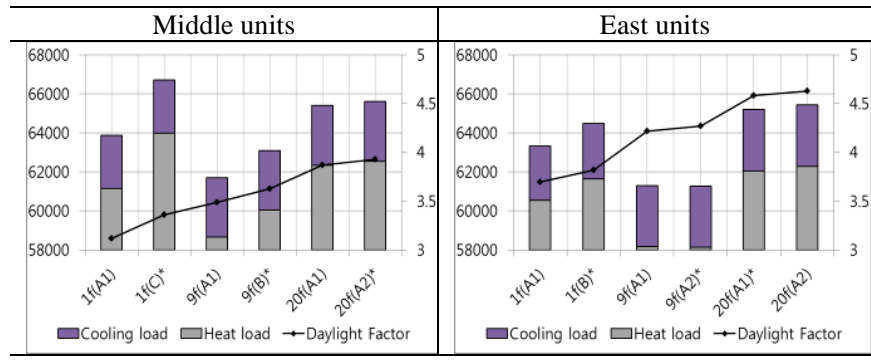

[Note] X: energy loads $\left(\mathrm{KWh} / \mathrm{m}^{2}\right), \mathrm{Y}: \mathrm{DF}(\%)$, * : better alternative

Fig. 3. Graph of Daylight Autonomy for all types of 20th floor.

If total area of the window is the same, the case to have the proper window area faced on the north will appear more evenly spread lighting than it without the window to the north. This can be drawn by calculating the proper depth with the previous formula. In the case with the same condition except for the location, A1 on the eastside was better and A2 on the middle was better by the proper daylight distribution (see Fig. 
2, Fig. 3). In the energy efficiency, the wider window tends to make more energy load. Though windows with the same area (A1 \& A2) were installed, the energy loads were different depending on the dwelling location such as the mid-unit in $20^{\text {th }}$ floor and east ones in $10^{\text {th }}$ and $20^{\text {th }}$ floors. Therefore, the window model with less energy load could be applied if the enough daylight were provided.

\section{B. Performance Depending on the Location of Units}

In the middle units, when the distance from the window became far, the ratio with proper illumination, i.e. DA drastically reduced despite the expansion of windows (Table V). However, in DF(see Table IV), though C type of the middle first floor had wider window area than $B$ type of the east unit, the DF of the farthest part from the window(1.98) was higher than it of the middle one(1.48). That was different that the illumination near the window (15.6) is lower than the middle point (15.6). Like this, the middle unit has more dynamic range in all locations, and the uniformity of daylight is relatively poor. On the other hand, in the daylight environment depending on the level of floor, there was a little difference between $9^{\text {th }}$ and $20^{\text {th }}$ floor, whereas, the difference from the first floor was big.Thus, the window area of the first floor should be wider than other layers(see Table VIII). In addition, if there were no north-facing window, the limit of the building depth should be considered as $7.76 \mathrm{~m}$ in the previous calculation. The WWR of the lowest floor should approximately be $30-35 \%(\mathrm{~A} \sim \mathrm{C})$ in order to satisfy more than $50 \% \mathrm{DA}$ in the floor area and more than $1.5 \% \mathrm{DF}$ in more than $80 \%$ of all floor area(see Table IV and V). These total window area coincided with $20-25 \%$ of the floor area. In addition, the strategy for increasing the uniformity of lighting should be applied because the lighting gap of the lowest floor between minimum and maximum points was close to 1.5-1.8 times of it of the $20^{\text {th }}$ floor.

TABLE VIII: ELEVATION DESIGN MODEL AND THEIR DETERMINANTS

\begin{tabular}{|c|c|c|c|c|}
\hline \multirow{3}{*}{ Story } & \multicolumn{2}{|c|}{ Middle units } & \multicolumn{2}{|c|}{ East-side units } \\
\hline & \multirow{2}{*}{\begin{tabular}{|l|} 
Model type \\
Determinant
\end{tabular}} & \multirow{2}{*}{ Façade design } & Model type & \multirow{2}{*}{ Façade design } \\
\hline & & & Determinant & \\
\hline \multirow[t]{2}{*}{$1 \mathrm{~F}$} & $\mathrm{C}$ & & $\mathrm{B}$ & \\
\hline & DF\&DA & & DF\&DA & \\
\hline \multirow{3}{*}{$9 \mathrm{~F}$} & B & \multirow{3}{*}{$\square$} & \multirow{3}{*}{\begin{tabular}{|c|}
$\mathrm{A} 2$ \\
DF\&DA \\
Energy loads
\end{tabular}} & \\
\hline & DF\&DA & & & \\
\hline & & & & \\
\hline \multirow[t]{3}{*}{$20 \mathrm{~F}$} & A 2 or A1 & & A1 & \multirow{3}{*}{$\square \square$} \\
\hline & A2:DF\&DA & & DAmax & \\
\hline & A1:Energy & & Energy loads & \\
\hline \multicolumn{3}{|c|}{ Model by illumination distribution } & \multicolumn{2}{|c|}{ Model by the whole factors } \\
\hline \multicolumn{3}{|c|}{ 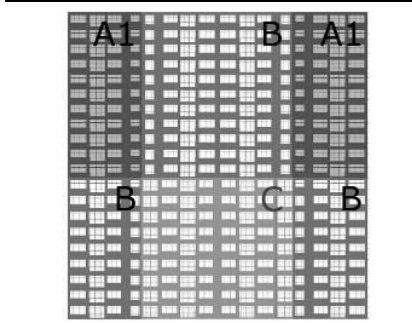 } & \multicolumn{2}{|c|}{ 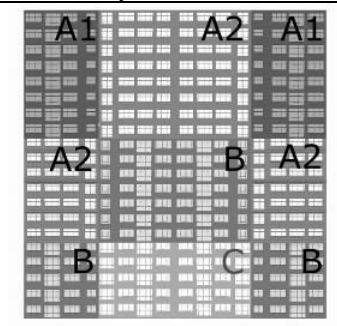 } \\
\hline
\end{tabular}

While the lighting distribution of $9^{\text {th }}$ floor was similar to it of $20^{\text {th }}$ floor, the differences of the energy consumption between $9^{\text {th }}$ and $20^{\text {th }}$ floor were significant. In addition, the energy consumption of the middle first floor with the poor lighting condition. Thus, the installation of awning and light shelve in the middle unit should be considered in order to supplement the disadvantages [1], [9]. Like this, in lower floors, if the visual comfort was the most important, models with lower energy efficiency could be surely selected; however, in upper floor level, the energy performance could be the top criteria.

\section{CONCLUSION}

This study focused on designing wall openings to ensure the appropriate daylight and the lower energy consumption. In addition, the suitable illumination is set for the visible comfort, and the space function. It is necessary to understand the indoor daylight distribution that can help enhance the performance of the building and the rationality of each floor plan. Therefore, this study investigated the direction how to change the elevation of the building comparing to WWR of four types depending on the effect of shading: $100 \%$ shaded, partial shaded, not shaded by adjacent buildings. The results were as follows: First, there was more clear difference in the DA than DF depending on the location. The intermediate unit had bigger illumination difference than the side units as the measuring point away from the window. Thus, WWR should be different in each dwelling in order to create the similar daylight environment(see Table VIII). The lower level the middle dwellings were located on in the flat-type apartment, the higher WWR was needed. However, that would make energy loads and the area with the excessive daylight levels increase. Therefore the integrated design decision would be needed. Shaded by the building from the same distance as the building height, WWR in the first floor, middle unit should increase more than $5 \%$ compared to it of the $20^{\text {th }}$ floor, and the gap of the overall illumination could reduce to $17 \%$ or less. However, when window area increased, due to power consumption and the excessive illumination, the shading installation or the high performance insulation materials and window system should be installed in lower part unlike the materials of upper floors. Second, if the impact of the shadow was negligible in the top story, there would be little difference in the daylight environment of upper part such as the 10th and $20^{\text {th }}$ floor of east units. However, the illumination of first floor and 9th floor was apparently different. The energy consumption was quite low in the intermediate stories. Therefore, the south-elevation of the flat-type apartment could be divided into more than three parts according to the grade of the disturbance of the daylight and the area faced with open air. The results of a comparison between the formula and the simulation calculation were drawn by the A1 window model. In that of the formula calculation, the illumination difference between the ground and the top floor was nearly $2 \% \mathrm{DF}$ and the top one was 1.9 times higher than the ground one. On the other hand, in the result of the simulation, the DF gap was just $0.75 \%$ and the top one was 1.24 times as high as the ground floor. The reason is that there were four northern windows though the depth of building was 
over the limits. In addition, the difference of the way to draw the results should be investigated and check the situation in real. The WWR of $1^{\text {st }}$ floor units having the poorest condition would set the widest window area and the façade design method should be different. The reason is that the range of the disturbance of the day-lighting changes depending on the distance between buildings. In addition, the depth of the building should be properly selected by calculating the range which light reaches the inside work plane, and the result would be different in all stories, due to change of the angle between the top point of the adjacent building and each floors. Therefore, changing the floor area in the same building to divide into several types would be more efficient in terms of the illumination and the energy performance.

Moreover, further research about the elevation of apartments would be required to compare the results of the energy consumption to the different condition of awning installation and transmittance of the window.

\section{REFERENCES}

[1] A. Tzempelikos and A. K. Athienitis, "The impact of shading design and control on building cooling and lighting demand," Solar Energy, vol. 81, pp. 369-382, 2007

[2] "LEED for new construction and major renovations. (2009). US Green Building Council, pp. 80, v2009, [Online]. Available: http://www.usgbc.org/LEED/

[3] K. K. Soo and J. H. Yong, "Comparison of the daylight criteria for the green building certification," Architectural Institute of Korea, vol. 25 , pp. 341-348, 2009

[4] Z. Rogers, "Daylight metric development using daylight autonomy calculation in the sensor placement optimization tool. boulder," Colorado, USA. Architectural Energy Corporation, 2006

[5] S. R. Chinnayeluka, "Performance assessment of innovative framing systems through building information modeling based energy simulation," Osmania University, pp. 32-71, 2011

[6] S. S. Young, "Comparison of assessment methods of building energy performance in domestic and foreign certificate systems of residential building," Korean Institute of Architectural Sustainable Environment and Building Systems, pp. 275-278, October, 2009.

[7] C. D. Sung and D. J. Seok, "A study on the evaluation of the residential environment efficiency by arrangement of multi-family residential buildings," Korean Institute of Architectural Sustainable Environment and Building Systems, vol. 9, pp. 57-64, 2009.

[8] T. Otis and C. F. Reinhart, "Daylighting rules of thumb," Havard University Graduate School of Design, March 2009.

[9] C. F. Reinhart, J. Mardaljevic, and Z. Rogers, "Dynamic daylight performance metrics for sustainable building design," LEUKOS, vol. 3 , pp. 7-31, 2006.

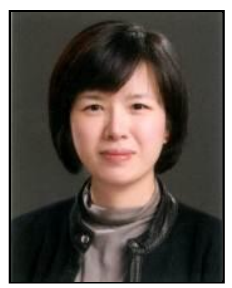

Ji-Eun Lee is currently an associate research fellow in Land \& Housing Institute. She conducted research on housing design incorporating environmental performance, design standards for the apartment renovation, and residential environment improvement. She is a member of board directors in Korea Institute of Building Information Modeling and the public design forum committee in Deajeon Metropolitan.

She acquired her Architect license, KIA. She was a senior architect in Samoo Architects and Engineers from 2004 to 2009.

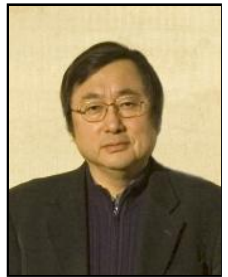

Kang Up Lee received A.B. and M. Arch. degree from University of California, Berkeley, and M.A.U.D. degree from Harvard University in 1981. $\mathrm{He}$ served as a chief of Urban Redevelopment Section and Architectural Research Section in Korea National Housing Corporation. He has joined the faculty of Department of Architecture at Hanyang University in Seoul in 1982. In 2009 he was appointed as the dean of College of Architecture. $\mathrm{He}$ has been teaching architectural design and history of architecture. He has been engaged in the research on architectural planning and history of architecture. He has also designed several buildings including university library of Hanyang University. Prof. Lee has held visiting appointments at the University of California, Berkeley. 